\title{
Effect of insulin on hind-limb and whole-body leucine and protein metabolism in fed and fasted lambs
}

\author{
BY V.H. ODDY*, D. B. LINDSAY†, P. J. BARKER AND A. J. NORTHROP \\ Agriculture and Food Research Council Institute of Animal Physiology, Babraham, \\ Cambridge CB2 $4 A T$
}

(Received 28 August $1986-$ Accepted 8 June 1987)

1. A combination of isotope-dilution and arterio-venous difference techniques was used to determine rates of leucine metabolism and protein synthesis and degradation in a hind-limb preparation (predominantly muscle) and the whole body of eight lambs fed on milk to appetite and eight lambs fasted from 24 to $48 \mathrm{~h}$.

2. Compared with fed lambs, fasted lambs showed decreased rates of protein synthesis in both whole body and hind-limb, and in hind-limb muscle, elevated rates of protein degradation.

3. The effects of two rates of insulin infusion on whole-body and hind-limb-muscle leucine metabolism, and in turn on protein metabolism, were determined. Insulin had no significant effect on leucine flux or oxidation (and hence protein synthesis and degradation) in whole-body or hind-limb muscle of fed lambs. In fasted lambs insulin progressively reduced arterial leucine concentration and whole-body leucine flux and oxidation, indicating a reduction in both protein synthesis and degradation. Insulin reduced the rate of leucine efflux from hind-limb muscle, which was followed by a reduction in leucine uptake. Insulin increased hind-limb-muscle glucose uptake in both fed and fasted lambs.

4. On the basis that hind-limb muscle was representative of skeletal muscle in general, we estimated that muscle accounted for the same percentage (about 27) of whole-body protein synthesis in both fed and fasted lambs. This percentage was unaffected by infusion of insulin, although the absolute rates differed in fed and fasted lambs.

In young lambs, about two-thirds of carcass growth between birth and 9 weeks of age can be skeletal muscle (calculated from values from Palsson \& Verges, 1952). The hormonal factors determining such growth have not been identified, but there is evidence that insulin is associated with increased growth (for example, see Prior \& Smith, 1982). Insulin increases the rate of protein synthesis in muscle of diabetic and fasted rats (Albertese et al. 1979; Garlick et al. 1983; Pain et al. 1983) but not in fed rats. This may be because the insulin concentrations found in fed animals are already maximal. However, in pigs insulin infusion did increase nitrogen retention (Fuller et al. 1977) and in lambs, although added insulin did not alter $\mathrm{N}$ balance, effects have been reported on plasma amino acid and urea concentrations (Sumner \& Weekes, 1983).

In the present experiments we have determined the effects of insulin infusions on protein metabolism in a hind-limb preparation, consisting largely of skeletal muscle, and the whole body of lambs either fed to maximum intake or fasted for a short period. Rates of protein synthesis and degradation in hind-limb were determined as described by Oddy \& Lindsay (1986). This technique also permits determination of whole-body protein metabolism. Although insulin did not affect protein metabolism in maximally fed lambs, the fall in insulin concentration during fasting can account for changes in the rate of proteolysis, but possibly not of synthesis.

\footnotetext{
Present addresses:

* New South Wales Department of Agriculture, Nutrition and Feeds Evalution Unit, Glenfield, NSW, 2167 Australia.

$\uparrow$ CSIRO Division of Tropical Animal Science, Tropical Cattle Research Centre, Box 5545, Rockhampton, Queensland 4701, Australia.
} 


\section{MATERIALS AND METHODS}

\section{Animals and surgical preparation}

Male lambs (eight Clun Forest and two Friesland) were removed from their mothers at $2 \mathrm{~d}$ of age, placed in individual cages, and bottle-fed on a reconstituted milk powder (Kidolac; Volac, Orwell, Herts) four times daily. After a training period of 4-7 d the lambs were offered milk from a reservoir from which they could drink at will. Milk intake was recorded daily, and the lambs were weighed three times weekly. Each litre of reconstituted milk contained $200 \mathrm{~g}$ dry matter, $4 \cdot 3 \mathrm{MJ}$ gross energy, $5 \mathrm{~g} \mathrm{~N}$ and $35 \mathrm{mmol}$ leucine. The age of the lambs at the time of experiment, their weight, growth rate and intake are shown in Table 1. Leucine intake was calculated from the leucine content of milk replacer and is uncorrected for losses which might have occurred upon digestion.

Catheters were implanted in the jugular vein, and carotid and femoral arteries at least 1 week before experiments, except where lambs were less than $10 \mathrm{~d}$ old in which case the minimum time between catheter placement and experiment was $3 \mathrm{~d}$. The deep femoral veins were cannulated, under local anaesthetic (Xylotox; Willows \& Francis, Bolton, Lancs), via the respective lateral saphenous veins (Domanski et al. 1974), on the day preceding the first experiment on each lamb. Each catheter was filled with sterile heparin saline solution (100 U heparin $/ \mathrm{ml}$ saline ( $9 \mathrm{~g}$ sodium chloride/1): Multiparin; Weddell Pharmaceuticals, Wrexham, Clwyd) and patency was maintained by flushing with heparin saline on every 2nd day. Catheters were $1.2 \mathrm{~mm}$ outside diameter, $0.8 \mathrm{~mm}$ inside diameter polyvinylchloride except those implanted in the femoral arteries which were $0.8 \mathrm{~mm}$ outside diameter, $0.5 \mathrm{~mm}$ inside diameter polyethylene (Dural Plastics, Dural, NSW, Australia).

Femoral arterial catheters were introduced via the medial saphenous artery and passed into the femoral artery so that the tip was approximately $30 \mathrm{~mm}$ distal to the bifurcation of the femoral and medial saphenous arteries. This position had been determined to be that which maximized the proportion of dose of $15 \mu \mathrm{m}$ microspheres injected into the femoral arterial catheter and subsequently recovered from muscle of lambs of $10-20 \mathrm{~kg}$. The distribution (\%) of $15 \mu \mathrm{m}$ microspheres injected into the femoral artery at this site, in four legs, was: muscle 58 (SE 4), bone 33 (SE 3), skin 9 (SE 2) (Oddy, 1986).

\section{Experimental procedure}

Experiments were carried out on fed and fasted lambs. Four experiments were conducted with lambs $10 \mathrm{~d}$ old or less (two while fed, two while fasted), eight with lambs $20-30 \mathrm{~d}$ old (four fed, four fasted), and four with lambs 50-60 d old (two fed, two fasted). The same lambs were used for both 'fed' and 'fasted' experiments, except for those less than $10 \mathrm{~d}$ of age, where different lambs were used for each experiment. The period of fasting varied from $24 \mathrm{~h}$ for lambs less than $11 \mathrm{~d}$ old, $36-40 \mathrm{~h}$ for those between 11 and $45 \mathrm{~d}$ old, and $48 \mathrm{~h}$ for lambs older than $45 \mathrm{~d}$, and, except for lambs less than $10 \mathrm{~d}$ old, commenced immediately after the 'fed' experiments. Water was freely available during the fasting period.

The experimental procedure and general handling of the animals was similar to that described previously (Oddy \& Lindsay, 1986). Each experiment consisted of an infusion of L- $\left[1-{ }^{14} \mathrm{C}\right]$ leucine (about $0.25 \mu \mathrm{Ci} / \mathrm{ml}$ saline; Amersham International plc, Amersham, Bucks), into the jugular vein at a constant rate $(0.4 \mathrm{ml} / \mathrm{min}$; about $0.1 \mu \mathrm{Ci} / \mathrm{min})$ for $300 \mathrm{~min}$. Simultaneous samples of blood (each about $10 \mathrm{ml}$ ) were withdrawn at about $1 \mathrm{ml} / \mathrm{min}$, into ice-cold tubes, from the carotid artery, and both femoral vein catheters, using a Desaga multichannel pump (Camlab Ltd, Cambridge) before, and at $30 \mathrm{~min}$ intervals from $120 \mathrm{~min}$ after, the start of $\mathrm{L}-\left[1-{ }^{14} \mathrm{C}\right]$ leucine infusion. From that time $(120 \mathrm{~min}$ after the start of $\left[{ }^{14} \mathrm{C}\right]$ leucine infusion), sterile saline was infused into one femoral artery at about $0 \cdot 4 \mathrm{ml} / \mathrm{min}$ (hereafter called the treated leg). After $60 \mathrm{~min}\left(180 \mathrm{~min}\right.$ after the start of $\left[{ }^{14} \mathrm{C}\right]$ leucine 
Table 1. Age, weight, growth rate and feed intake (in terms of gross energy, nitrogen and leucine) and estimated output of carbon dioxide of the lambs used in the present study

(Values shown are means with their standard errors for eight fed and eight fasted lambs)

\begin{tabular}{|c|c|c|c|c|c|c|}
\hline & \multicolumn{3}{|c|}{ Fed } & \multicolumn{3}{|c|}{ Fasted ${ }^{*}$} \\
\hline & Mean & $\mathbf{S E}$ & Range & Mean & SE & Range \\
\hline Age (d) & 29 & 7 & $8-64$ & 30 & 7 & $9-60$ \\
\hline Wt (kg) & $12 \cdot 2$ & $2 \cdot 0$ & - & $11 \cdot 9$ & $1 \cdot 9$ & - \\
\hline Growth rate $(\mathrm{g} / \mathrm{d})$ & 314 & 18 & - & $-\dagger$ & - & 一 \\
\hline \multicolumn{7}{|l|}{ Intake of } \\
\hline Gross energy $(\mathrm{MJ} / \mathrm{d})$ & $10 \cdot 5$ & $1 \cdot 0$ & - & 0 & - & - \\
\hline$N(g / d)$ & $16 \cdot 4$ & $1 \cdot 6$ & - & 0 & - & - \\
\hline Leucine $(\mu \mathrm{mol} / \mathrm{min})$ & $58 \cdot 9$ & $5 \cdot 8$ & 一 & 0 & - & - \\
\hline Carbon dioxide output ( $\mathrm{mmol} / \mathrm{min}$ ) & $4 \cdot 8$ & $0 \cdot 6$ & - & $4 \cdot 0$ & 0.5 & 一 \\
\hline
\end{tabular}

* Period of fast varied from $24 \mathrm{~h}$ for lambs less than $11 \mathrm{~d}$ of age to $48 \mathrm{~h}$ where the lambs were older than $50 \mathrm{~d}$. Water was available during the fasting period.

$\dagger$ Period was too short to estimate rate of live-weight loss.

infusion) the saline infusion was replaced by an insulin (bovine soluble insulin; Wellcome, Beckenham, Kent) infusion at about $4 \mathrm{mU} / \mathrm{kg}$ per min (first insulin infusion), and after a further $60 \mathrm{~min}$ ( $240 \mathrm{~min}$ after the start of $\left[{ }^{14} \mathrm{C}\right]$ leucine infusion) this was replaced by an infusion of insulin at about $20 \mathrm{mU} / \mathrm{kg}$ per $\min$ for $60 \mathrm{~min}$ (second insulin infusion). These rates of insulin infusion were intended to increase the concentration of insulin in plasma from the treated leg to approximately twice and five times the concentration of that during saline infusion in fed lambs. The femoral artery of the contralateral leg was not infused with saline or insulin, and remained as a control to determine the local effect of insulin on hindlimb metabolism. After $300 \mathrm{~min}$, the $\mathrm{L}-\left[1-{ }^{14} \mathrm{C}\right]$ leucine infusion was stopped, and blood flow through the sampled tissues of both hind-limbs was determined using tritiated water (Oddy et al. 1981). Whole blood was used for the determination of concentration and specific radioactivity (SRA) of carbon dioxide, concentration of ${ }^{3} \mathrm{H}_{2} \mathrm{O}$ for blood-flow determination and packed cell volume (PCV). Plasma was removed, and stored at $-20^{\circ}$ until analysis for leucine and 4-methyl-2-oxo-pentanoic acid (the keto acid of leucine, $\alpha$-ketoisocaproic acid; KIC) concentrations and SRA, and concentrations of glucose and insulin.

To determine whether insulin was affecting blood flow during each experiment, indocyanine green dye (Hynson, Westcott \& Dunning; Baltimore, Maryland, USA) was co-infused into the femoral artery at about $0.3 \mathrm{mg} / \mathrm{min}$ (about $0.4 \mathrm{ml} / \mathrm{min}$ ) for $12 \mathrm{~min}$ during the saline and second insulin infusions. On each occasion three matched carotid arterial and femoral venous pairs of blood samples were withdrawn between 6 and 12 min of indocyanine green co-infusion. The concentration of indocyanine green dye was determined in plasma. This procedure could provide only an index of blood flow, for there was incomplete recovery of dye from the deep femoral vein after infusion into the corresponding artery.

Two additional experiments were conducted to determine the effect of adrenaline on hind-limb-muscle protein metabolism. These were carried out using fed lambs, older than $50 \mathrm{~d}$, which had been used for the insulin experiments described previously. The experimental protocol was similar to that for insulin, except only one rate of adrenaline infusion was used per experiment, and it continued for $2 \mathrm{~h}$. In one experiment adrenaline (Sigma Chemical Co., Poole, Dorset) was infused into a femoral artery at about $9 \mu \mathrm{g} / \mathrm{min}$; in the second at about $2 \mu \mathrm{g} / \mathrm{min}$. Sampling was as described for the insulin experiments. 


\section{Analytical}

The methods used to determine the concentrations and SRA of $\mathrm{CO}_{2}$, leucine and $\mathrm{KIC}$, together with those involved in the measurement of radioactivity, are described by Oddy \& Lindsay (1986). The tritium content of blood, for blood-flow determination, was measured as described by Pappenheimer \& Setchell (1972). Glucose was determined enzymatically on perchloric filtrates of plasma by the method of Werner et al. (1970) using a Boehringer Kit (Kit no. 124036; Boehringer Mannheim, Mannheim, FRG). The procedure of Gutmann \& Wahlfeld (1974) was used to determine the concentration of $\mathrm{L}(+)$ lactate in perchloric filtrates of plasma. Plasma insulin concentration was measured by radioimmunoassay (Insulin Radioimmunoassay Kit, IM78; Amersham International plc), using human insulin standards. Where values exceeded $160 \mu \mathrm{U} / \mathrm{ml}$ (the upper limit of the assay), plasma was diluted until values lay within the range of the standard curve. The concentration of indocyanine green dye in plasma was determined from the optical density at $805 \mathrm{~nm}$.

\section{Whole animal}

\section{Calculations}

(a) Leucine flux $(\mu \mathrm{mol} / \mathrm{min})=I /$ leucine SRA, where $I$ is the infusion rate (disintegrations/min (dpm) per $\mathrm{min}$ ) and SRA is the mean arterial specific radioactivity of leucine $(\mathrm{dpm} / \mu \mathrm{mol})$. The term flux as used here is equivalent to that of 'disposal rate' as defined by Waterlow et al. (1978).

(b) Proportion of $\mathrm{CO}_{2}$ production derived from oxidation of leucine $=X /$ leucine SRA, where $X$ is the mean SRA of arterial $\mathrm{CO}_{2}(\mathrm{dpm} / \mu \mathrm{mol})$ and leucine SRA is the mean SRA of arterial leucine $(\mathrm{dpm} / \mu \mathrm{mol})$.

(c) The total amount of leucine oxidized $(\mu \mathrm{mol} / \mathrm{min})$ was calculated as the proportion of $\mathrm{CO}_{2}$ production derived from oxidation of leucine times the rate of output of $\mathrm{CO}_{2}$.

Because the rate of $\mathrm{CO}_{2}$ output was not measured, an estimate for fed lambs was obtained from values previously collected in this laboratory (D. B. Lindsay, R. Vincent, R. Bickerstaffe, D. W. Pethick, A. J. Northrop and J. C. Mackenzie, unpublished results). $\mathrm{CO}_{2}$ excretion rate of fed Clun Forest lambs was obtained from a relation between live weight $^{0.75}(X ; \mathrm{kg})$ and total $\mathrm{CO}_{2}$ output $(Y ; \mathrm{mmol} / \mathrm{min})$ :

$$
Y=0.723 X+0.182, \quad r 0.94, \quad P<0.01, \quad n 23 .
$$

Values for fasted lambs were deduced from the above and from Walker (1967), where $\mathrm{CO}_{2}$ output of fasted lambs was $15 \%$ less than that of fed lambs of similar weight. The mean values derived from these procedures are given in Table 1. No correction was made for incomplete recovery of ${ }^{14} \mathrm{CO}_{2}$ due to loss of ${ }^{14} \mathrm{CO}_{2}$ in various fixation reactions within the body. These typically comprise about $10 \%$ of $\mathrm{CO}_{2}$ flux in the body of sheep (Whitelaw et al. 1972), and appear to be unaltered by fasting for $3 \mathrm{~d}$ (Pell et al. 1986).

(d) The fractional rates of protein synthesis and degradation in the whole body were calculated as described by Waterlow et al. (1978).

(1) Fractional rate of protein synthesis:

$$
K_{s} / \mathrm{d}=\frac{\text { (leucine flux }- \text { leucine oxidation }) \times 1 \cdot 44}{\text { leucine content of whole body }}
$$

(2) fractional rate of protein degradation:

$$
K_{d} / \mathrm{d}=\frac{\text { (leucine flux }- \text { leucine intake }) \times 1.44}{\text { leucine content of whole body }},
$$


where leucine intake, flux and oxidation are expressed as $\mu \mathrm{mol} / \mathrm{min}$. In fed lambs leucine intake was the measured leucine content of milk replacer multiplied by milk intake, uncorrected for any utilization of leucine by the portal-drained viscera. The value used for leucine content of the whole body was $97.88 \mathrm{mmol} / \mathrm{kg}$ live weight (Williams, 1978). Absolute rates of protein synthesis and degradation $(\mathrm{g} / \mathrm{d})$ were calculated as for fractional rate with the additional information that protein content of milk-fed lambs was $190 \mathrm{~g} / \mathrm{kg}$ live weight (Agricultural Research Council, 1980). On this basis the leucine content of the whole-body protein was $6.76 \%$. An additional estimate of the rate of protein degradation in the whole body of fed lambs was obtained by subtracting the protein content of the measured rate of live-weight gain from the estimated rate of protein synthesis.

Hind-limb. Measurement of protein metabolism in our hind-limb preparation (predominantly muscle) employed determination of arterio-venous differences in concentration and specific radioactivity of leucine, $\mathrm{KIC}$ and $\mathrm{CO}_{2}$, together with blood flow as described by Oddy \& Lindsay (1986). Fig. 1 shows the outline of the kinetic model used to calculate leucine and KIC interconversion and oxidation, and in turn the simultaneous estimates of protein synthesis, gain and degradation. Briefly, the assumptions used in the technique are that (1) in muscle, free-leucine and KIC are single well-mixed pools, freely exchanging with their counterparts in plasma; (2) the contribution of radioactive leucine from that bound in protein to the muscle free-leucine pool was small during the course of the measurement; (3) the SRA of the precursor for $\mathrm{CO}_{2}$ derived from oxidation of leucine is approximated by femoral venous KIC SRA; (4) that blood flow through the hind-limb during the sampling period was similar to that subsequently measured.

The fractional rates of muscle protein synthesis and degradation were calculated from rates of protein synthesis and degradation derived from this model:

$$
\begin{aligned}
& K_{s}=\frac{R_{41} \times 1.44}{\text { leucine content of muscle }}, \\
& K_{d}=\frac{R_{14} \times 1.44}{\text { leucine content of muscle }},
\end{aligned}
$$

where $R_{41}$ is the rate of transfer of muscle free-leucine to protein, and $R_{14}$ is the rate of transfer of muscle-protein leucine to the muscle free-leucine pool $(\mu \mathrm{mol} / \mathrm{kg}$ per min; Fig. 1). The leucine content of hind-limb muscle of lambs was $93.61 \mathrm{mmol} / \mathrm{kg}$ wet weight (Oddy \& Lindsay, 1986).

The fractional rate of muscle protein gain $\left(K_{g} / \mathrm{d}\right)$ was calculated as described by Waterlow et al. (1978):

$$
K_{g}=K_{s}-K_{d}
$$

An estimate of the rate of protein metabolism in all skeletal muscle was derived from the proportion of skeletal muscle in lambs $(0.275$; Palsson \& Verges, 1952) and the belief that our hind-limb-preparation samples blood draining predominantly from skeletal muscle (Domanski et al. 1974).

Blood flow through the sampled tissues of the hind-limb (as determined using tritiated water) was calculated as described by Oddy et al. (1981). This procedure provides flow as $\mathrm{ml} / \mathrm{min}$ per unit weight of sampled tissue. Blood flow index (from measurement of indocyanine green dye) was calculated as for blood flow in human forearm muscle using Evans blue dye (Andres et al. 1962). 


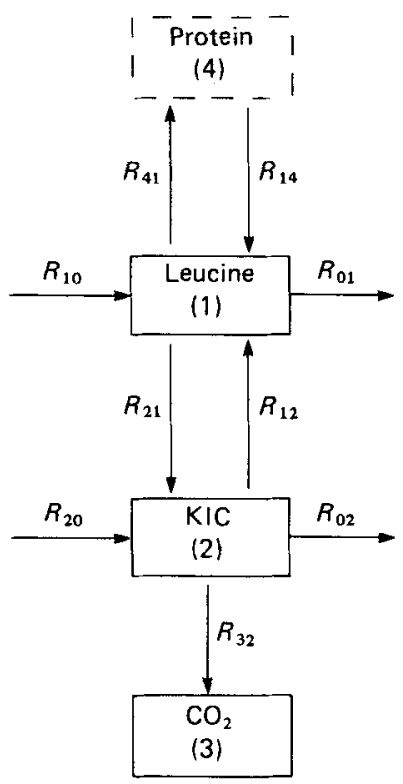

Fig. 1. The model of leucine and $\alpha$-ketoisocaproic acid (KIC) used to determine the rates of protein synthesis $\left(R_{41}\right)$ and degradation $\left(R_{14}\right)$ in hind limb muscle. Rates $R_{10}$ and $R_{20}$ represent gross transfer of leucine and KIC respectively from arterial plasma. Outputs $R_{01}$ and $R_{02}$ are corresponding flows into deep femoral vein plasma. $R_{32}$ is the output of leucine-derived carbon dioxide from muscle. $R_{21}$ and $R_{12}$ represent rate constants for the transamination reaction between leucine and KIC. The convention used is that, for example, $R_{41}$ refers to the rate of transfer to pool 4 (protein) from pool 1 (leucine). 0 represents sources or disposal external to the tissue.

\section{Statistical procedures}

Two-way analysis of variance was used to determine the effect of fasting and insulin infusion. Significance of differences between means were estimated using Student's $t$ test; unpaired for comparison between treatments, paired for comparison between treated and control legs. Because our primary interest was of the effects of fasting and insulin on protein metabolism, values were pooled for lambs of differing age. However, where there was likely to be differences due to age these were compared by allocating lambs to one of two agegroups, $<25 \mathrm{~d}$ or $>25 \mathrm{~d}$ (four fed and four fasted lambs per age-group), before analysis of variance.

\section{RESULTS}

Concentration of insulin, specific radioactivity of leucine, $\mathrm{KIC}$ and $\mathrm{CO}_{2}$, and tissue blood flow

The concentration of insulin in peripheral blood plasma increased during insulin infusion (Table 2). In femoral vein blood from the infused leg the concentration of insulin was consistently elevated compared with that from the control leg. There was no significant difference in the concentration of insulin during saline infusion, or in the magnitude of the change in insulin concentration following insulin infusion, in lambs of different ages. In lambs of less than $25 \mathrm{~d}$ of age the concentration of insulin during saline infusion was 246 (SE 140) and 6 (SE 5) $\mu \mathrm{U} / \mathrm{ml}$ in fed and fasted lambs respectively, whereas in lambs older than $25 \mathrm{~d}$ the corresponding values were 321 (SE 126) in fed lambs, and 13 (SE 9) $\mu \mathrm{U} / \mathrm{ml}$ in fasted lambs. 
Table 2. Concentration of insulin in femoral vein plasma during saline $(9 \mathrm{~g}$ sodium chloride/l) and insulin infusions

(Values are means with their standard errors for eight fed and eight fasted lambs; plasma concentration of immunoreactive insulin is expressed as $\mu \mathrm{U} / \mathrm{ml}$ )

\begin{tabular}{|c|c|c|c|c|c|c|}
\hline & \multicolumn{2}{|c|}{ Saline infusion } & \multicolumn{2}{|c|}{$\begin{array}{l}\text { First insulin } \\
\text { infusion }{ }^{\dagger}\end{array}$} & \multicolumn{2}{|c|}{$\begin{array}{l}\text { Second insulin } \\
\text { infusion }\end{array}$} \\
\hline & Mean & $\mathrm{SE}$ & Mean & $\mathrm{SE}$ & Mean & $\mathrm{SE}$ \\
\hline \multicolumn{7}{|l|}{ Fed } \\
\hline Control leg & ND & - & $328^{\mathrm{a}}$ & $117 \cdot 2$ & $1328^{b}$ & $142 \cdot 4$ \\
\hline Treated leg & $283^{\mathrm{a}}$ & $88 \cdot 8$ & $710^{\mathrm{a}}$ & $192 \cdot 1$ & $1680^{\mathrm{b}}$ & 117.0 \\
\hline \multicolumn{7}{|l|}{ Fasted } \\
\hline Control leg & ND & - & $31^{\mathrm{b}}$ & $7 \cdot 1$ & $960^{\circ}$ & $148 \cdot 7$ \\
\hline Treated leg & $8^{a}$ & $4 \cdot 4$ & $282^{\mathrm{b} * *}$ & $36 \cdot 1$ & $1558^{c *}$ & $130 \cdot 8$ \\
\hline
\end{tabular}

ND, Not determined

a.b.e Means with unlike superscript letters were significantly different $(P<0 \cdot 01)$. Differences between legs due to infusion were significantly different: ${ }^{*} P<0.01,{ }^{* *} P<0.001$.

$\dagger$ First insulin infusion, abnout $4 \mathrm{mU} / \mathrm{kg}$ per min; second insulin infusion, about $20 \mathrm{mU} / \mathrm{kg}$ per min.

The values shown in Table 3 were used to derive the measurements of whole-body and hind-limb-muscle leucine and protein metabolism shown in Tables 4-6 (pp. 445-447). While the lambs were fed, the amounts of radioactivity (expressed as $\mathrm{dpm} / \mathrm{ml}$ plasma or blood) in leucine, $\mathrm{KIC}$ and $\mathrm{CO}_{2}$ in arterial blood were reasonably constant across infusion periods, variation was typically less than $5 \%$ of the mean. In fasted lambs there was greater variation in the amount of plasma leucine radioactivity, principally due to the effects of insulin treatment, where, at the highest rate of insulin infusion, the amount of radioactivity in plasma leucine was $65 \%$ of that during the saline infusion. Thus variation in SRA predominantly reflected changes in concentrations of leucine, $\mathrm{KIC}$ and $\mathrm{CO}_{2}$ rather than the amounts of radioactivity in each component in plasma or blood.

There was no significant difference between the rate of blood flow through the sampled tissues of the hind-limb in fed and fasted lambs (mean values were 244 (SE 21) and 244 (SE 16) $\mathrm{ml} / \mathrm{min}$ per $\mathrm{kg}$ respectively) but PCV was lower $(P<0.05)$ in fasted lambs, 0.239 (SE 0.009), compared with 0.277 (SE 0.013) in fed lambs. Blood flow index was not significantly affected by infusion of insulin, being 247 (SE 51) $\mathrm{ml} / \mathrm{min}$ during saline infusion, and 291 (SE 82) $\mathrm{ml} / \mathrm{min}$ at the higher rate of insulin infusion. Thus the rate of blood flow measured at the end of each experiment was used for calculation of leucine and protein metabolism in hind-limb muscle during treatment with saline and insulin.

\section{Effect of insulin on arterial leucine and $K I C$ concentrations}

The concentrations of leucine and KIC in arterial blood are shown in Fig. 2( $a$ and $b)$. Before infusion of insulin, there was no significant difference in arterial leucine concentration due to fasting. During insulin infusion, while arterial leucine concentration remained unaltered in fed lambs, there was a decline $(P<0.05)$ in fasted lambs to values about one-third of those before insulin infusion. Arterial KIC concentrations were more than two-fold higher $(P<0.05)$ in the fasted compared with the fed lambs before insulin infusion, but, following infusion of insulin in fasted lambs, were reduced $(P<0.05)$ to values comparable to those of fed lambs. Insulin had no significant effect on the arterial KIC concentration of fed lambs. 
Table 3. The concentration and specific radioactivity $(S R A)$ of leucine and $\alpha$-ketoisocaproic acid $(K I C)$ in plasma, and carbon dioxide in blood from the carotid artery $(A)$, femoral veins from the side infused with insulin $(T)$ and the contralateral uninfused side $(C)$

(Each value is the mean of at least two samples taken during each of the saline $(9 \mathrm{~g}$ sodium chloride/l) or two insulin infusion periods, for eight fed and eight fasted lambs)

\begin{tabular}{|c|c|c|c|c|c|c|c|}
\hline \multirow[b]{2}{*}{$\begin{array}{l}\text { Treatment and } \\
\text { infusion }\end{array}$} & \multirow[b]{2}{*}{ Site } & \multicolumn{2}{|c|}{ Leucine } & \multicolumn{2}{|c|}{$\mathrm{KIC}$} & \multicolumn{2}{|r|}{$\mathrm{CO}_{2}$} \\
\hline & & $\mu \mathbf{M}$ & $\begin{array}{c}\text { SRA } \\
(\mathrm{dpm} / \mathrm{nmol})\end{array}$ & $\mu \mathrm{M}$ & $\begin{array}{c}\text { SRA } \\
(\mathrm{dpm} / \mathrm{nmol})\end{array}$ & $\mathrm{mM}$ & $\begin{array}{c}\text { SRA } \\
(\mathrm{dpm} / \mathrm{mmol})\end{array}$ \\
\hline \multicolumn{8}{|l|}{ Fed } \\
\hline Saline & $\begin{array}{l}\mathrm{A} \\
\mathrm{T} \\
\mathrm{C}\end{array}$ & $\begin{array}{l}184.6 \\
159.6 \\
149.9\end{array}$ & $\begin{array}{l}2 \cdot 58 \\
2 \cdot 34 \\
2 \cdot 32\end{array}$ & $\begin{array}{l}10 \cdot 3 \\
12 \cdot 5 \\
12 \cdot 4\end{array}$ & $\begin{array}{l}2.04 \\
1.96 \\
1.93\end{array}$ & $\begin{array}{l}27 \cdot 0 \\
29 \cdot 4 \\
29 \cdot 5\end{array}$ & $\begin{array}{l}5.56 \\
5.61 \\
5.56\end{array}$ \\
\hline Insulin 1 & $\begin{array}{l}\mathrm{A} \\
\mathrm{T} \\
\mathrm{C}\end{array}$ & $\begin{array}{l}169 \cdot 1 \\
140 \cdot 3 \\
140 \cdot 8\end{array}$ & $\begin{array}{l}3 \cdot 11 \\
2 \cdot 77 \\
2 \cdot 69\end{array}$ & $\begin{array}{l}10 \cdot 0 \\
11.8 \\
12.0\end{array}$ & $\begin{array}{l}2 \cdot 35 \\
2 \cdot 36 \\
2 \cdot 38\end{array}$ & $\begin{array}{l}26 \cdot 7 \\
28 \cdot 9 \\
28 \cdot 8\end{array}$ & $\begin{array}{l}6 \cdot 14 \\
6 \cdot 11 \\
6 \cdot 29\end{array}$ \\
\hline Insulin 2 & $\begin{array}{l}\mathrm{A} \\
\mathrm{T} \\
\mathrm{C}\end{array}$ & $\begin{array}{l}165 \cdot 1 \\
134 \cdot 7 \\
134 \cdot 6\end{array}$ & $\begin{array}{l}3 \cdot 11 \\
2 \cdot 95 \\
2 \cdot 91\end{array}$ & $\begin{array}{r}9.7 \\
11.4 \\
11.4\end{array}$ & $\begin{array}{l}2 \cdot 27 \\
2 \cdot 70 \\
2 \cdot 02\end{array}$ & $\begin{array}{l}26 \cdot 4 \\
28 \cdot 7 \\
28 \cdot 6\end{array}$ & $\begin{array}{l}5.72 \\
5.98 \\
5.99\end{array}$ \\
\hline $\begin{array}{l}\text { Fasted } \\
\text { Saline }\end{array}$ & $\begin{array}{l}\mathrm{A} \\
\mathrm{T} \\
\mathrm{C}\end{array}$ & $\begin{array}{l}161 \cdot 5 \\
163 \cdot 1 \\
164 \cdot 6\end{array}$ & $\begin{array}{l}4 \cdot 23 \\
3 \cdot 55 \\
3 \cdot 49\end{array}$ & $\begin{array}{l}22 \cdot 5 \\
26 \cdot 6 \\
25 \cdot 4\end{array}$ & $\begin{array}{l}2 \cdot 84 \\
2 \cdot 74 \\
2 \cdot 50\end{array}$ & $\begin{array}{l}23 \cdot 7 \\
25 \cdot 7 \\
25 \cdot 7\end{array}$ & $\begin{array}{l}6 \cdot 16 \\
6 \cdot 13 \\
6 \cdot 06\end{array}$ \\
\hline Insulin 1 & $\begin{array}{l}\mathrm{A} \\
\mathrm{T} \\
\mathrm{C}\end{array}$ & $\begin{array}{l}118 \cdot 2 \\
110 \cdot 5 \\
123 \cdot 7\end{array}$ & $\begin{array}{l}5 \cdot 38 \\
4 \cdot 55 \\
4 \cdot 17\end{array}$ & $\begin{array}{l}19.6 \\
21.6 \\
21.8\end{array}$ & $\begin{array}{l}3 \cdot 16 \\
3 \cdot 17 \\
2 \cdot 92\end{array}$ & $\begin{array}{l}23 \cdot 4 \\
24 \cdot 9 \\
25 \cdot 4\end{array}$ & $\begin{array}{l}7.22 \\
7.21 \\
6.84\end{array}$ \\
\hline Insulin 2 & $\begin{array}{l}\mathrm{A} \\
\mathrm{T} \\
\mathrm{C}\end{array}$ & $\begin{array}{l}49 \cdot 5 \\
47 \cdot 9 \\
48 \cdot 9\end{array}$ & $\begin{array}{l}9 \cdot 05 \\
7 \cdot 17 \\
6 \cdot 81\end{array}$ & $\begin{array}{l}8 \cdot 5 \\
7 \cdot 9 \\
8 \cdot 5\end{array}$ & $\begin{array}{l}4 \cdot 74 \\
4 \cdot 49 \\
4 \cdot 11\end{array}$ & $\begin{array}{l}21 \cdot 9 \\
23 \cdot 6 \\
23 \cdot 2\end{array}$ & $\begin{array}{l}4.96 \\
5 \cdot 53 \\
5 \cdot 22\end{array}$ \\
\hline & SE & $10 \cdot 9$ & $0 \cdot 31$ & 1.8 & 0.27 & 0.7 & $0 \cdot 62$ \\
\hline
\end{tabular}

dpm, Disintegrations/min,

Insulin 1, first insulin infusion, about $4 \mathrm{mU} / \mathrm{kg}$ per min; Insulin 2, second insulin infusion, about $20 \mathrm{mU} / \mathrm{kg}$ per min.

\section{Metabolism of leucine and protein in the whole body}

Fasting resulted in a decline $(P<0.01)$ in leucine flux and oxidation. In addition, the percentage of leucine flux oxidized declined from 13.4 to $10.1(P<0.05)$ and the percentage of whole-body $\mathrm{CO}_{2}$ derived from oxidation of leucine fell from 0.22 to $0.11(P<0.01)$ respectively in fed and fasted lambs. The infusion of insulin did not significantly affect leucine flux or oxidation in fed lambs, but in fasted lambs insulin infusion resulted in a progressive decline in both the flux and oxidation of leucine (Table 4).

Compared with fed lambs, fasted lambs had a decreased rate of protein gain in the whole body $(P<0.01)$, due primarily to a reduced rate of protein synthesis $(P<0.01)$. Protein degradation in the whole body (as assessed from rate of leucine flux minus intake) increased $(P<0.05)$ during fasting (Table 4). In terms of absolute rate, protein synthesis in fed lambs was $207 \mathrm{~g} / \mathrm{d}$ compared with $122 \mathrm{~g} / \mathrm{d}$ in fasted lambs, while degradation was $71 \mathrm{~g} / \mathrm{d}$ in fed and $134 \mathrm{~g} / \mathrm{d}$ in fasted lambs. However, when protein degradation was calculated as the difference between protein synthesis and the amount of protein in live-weight gain of fed sheep, rather than as flux minus intake, the estimated rate of protein degradation was not different to that during fasting, being $146 \mathrm{~g} / \mathrm{d}$ in fed and $122 \mathrm{~g} / \mathrm{d}$ in fasted lambs.

Insulin had no significant effect on the rate of protein synthesis, degradation or gain in fed lambs. In fasted lambs, however, the higher level of insulin was associated with reduced 

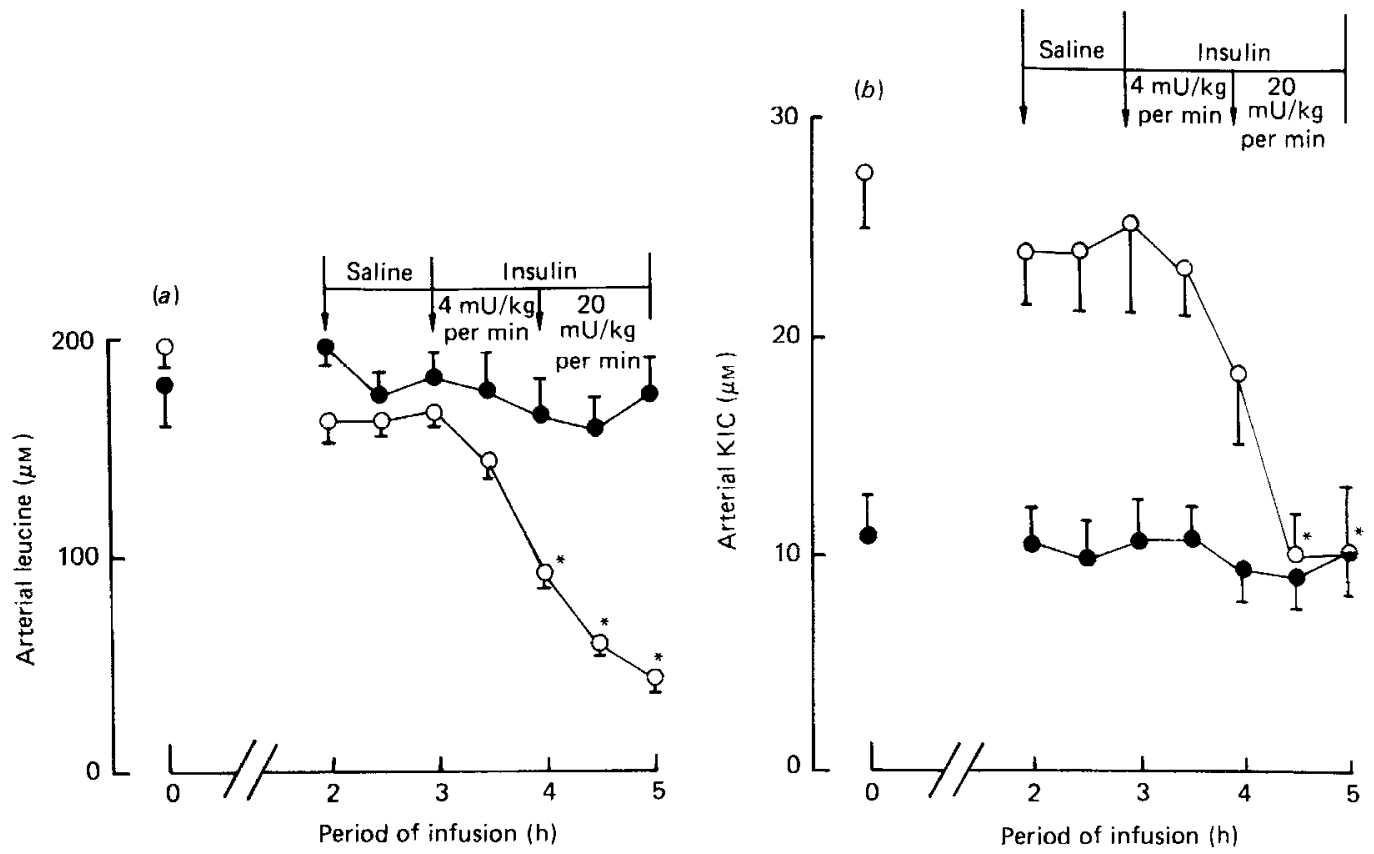

Fig. 2. The effect of insulin on $(a)$ arterial leucine and (b) arterial $\alpha$-ketoisocaproic acid (KIC) concentrations. Values shown are means with their standard errors represented by vertical bars for eight fed $(O)$ and eight fasted lambs $(O){ }^{*}$ Mean values were significantly different to those for the saline $(9 \mathrm{~g}$ sodium chloride/1) infusion period $(P<0.05)$.

Table 4. Leucine flux and oxidation, and fractional rate of protein synthesis $\left(\mathrm{K}_{\mathrm{s}}\right)$, degradation $\left(\mathrm{K}_{\mathrm{d}}\right)$ and gain $\left(\mathrm{K}_{\mathrm{g}}\right)$ in the whole body of eight fed and eight fasted lambs infused with insulin

\begin{tabular}{|c|c|c|c|c|c|c|}
\hline \multirow[b]{2}{*}{ Treatment } & \multirow{2}{*}{$\begin{array}{c}\text { Saline infusion } \\
\text { ( } 9 \text { g sodium) } \\
\text { (chloride } / 1)\end{array}$} & \multirow{2}{*}{$\begin{array}{l}\text { First insulin } \\
\text { infusion } \dagger\end{array}$} & \multirow{2}{*}{$\begin{array}{l}\text { Second insulin } \\
\text { infusion } \dagger\end{array}$} & \multirow[b]{2}{*}{$\mathrm{SE}$} & \multicolumn{2}{|c|}{ Effect of } \\
\hline & & & & & Fasting & Insulin \\
\hline \multicolumn{7}{|c|}{ Leucine flux ( $\mu \mathrm{mol} / \mathrm{kg}$ per min) } \\
\hline Fed & $7 \cdot 74$ & $6 \cdot 49$ & 6.46 & \multirow{2}{*}{0.57} & \multirow{2}{*}{ ** } & \multirow{2}{*}{ ** } \\
\hline Fasted & $5 \cdot 29^{\mathrm{a}}$ & $4 \cdot 14^{n}$ & $2.47^{\circ} f$ & & & \\
\hline \multicolumn{7}{|c|}{ Carbon dioxide derived from leucine $(\mu \mathrm{mol} / \mathrm{kg}$ per $\mathrm{min})$} \\
\hline Fed & 0.86 & 0.87 & 0.82 & \multirow{2}{*}{$0-07$} & \multirow{2}{*}{ ** } & \multirow{2}{*}{$*$} \\
\hline Fasted & $0 \cdot 52^{\mathrm{a}}$ & $0 \cdot 48^{3}$ & $\left.0 \cdot 19^{t} \quad\right\}$ & & & \\
\hline \multicolumn{7}{|l|}{$K_{8}(/ \mathrm{d})$} \\
\hline Fed & $0 \cdot 101$ & $0-083$ & $0.083\}$ & \multirow{2}{*}{0.008} & \multirow{2}{*}{$* *$} & \multirow{2}{*}{$* *$} \\
\hline Fasted & $0.070^{\mathrm{a}}$ & $0.054^{\mathrm{a}}$ & $0.034^{\mathrm{b}} \delta$ & & & \\
\hline \multicolumn{7}{|l|}{$K_{d}(/ \mathrm{d})$} \\
\hline Fed & 0.043 & $0 \cdot 025$ & 0.024 & \multirow{2}{*}{0.009} & \multirow[t]{2}{*}{$*$} & \multirow{2}{*}{$*$} \\
\hline Fasted & $0.078^{\mathrm{a}}$ & $0.061^{a}$ & $\left.0.036^{\mathrm{b}}\right\}$ & & & \\
\hline \multicolumn{7}{|l|}{$K_{g}(/ \mathrm{d})$} \\
\hline Fed & $0 \cdot 058$ & $0 \cdot 058$ & $0.059\}$ & \multirow{2}{*}{0.003} & \multirow{2}{*}{$* *$} & \multirow{2}{*}{ NS } \\
\hline Fasted & $-0 \cdot 008^{a}$ & $-0.007^{x}$ & $\left.-0.002^{h}\right\}$ & & & \\
\hline
\end{tabular}

NS, not significant.

a, h,e Mean values with unlike superscript letters were significantly different $(P<0.05)$.

${ }^{*} \mathrm{P}<0.05,{ }^{* *} P<0.01$; there was no significant interaction between the effects of fasting and insulin.

$\dagger$ First insulin infusion, about $4 \mathrm{mU} / \mathrm{kg}$ per min; second insulin infusion, about $20 \mathrm{mU} / \mathrm{kg}$ per min. 
Table 5. Effect of age on fractional and absolute rates of protein synthesis and degradation in the whole body of four fed and four fasted lambs

\begin{tabular}{cccccccc}
\hline & \multicolumn{2}{c}{ Protein synthesis } & & \multicolumn{3}{c}{ Protein degradation } \\
\cline { 2 - 3 } Age & $/ \mathrm{d}$ & $\mathrm{g} / \mathrm{d}$ & & $/ \mathrm{d}$ & $\dagger$ & $\mathrm{g} / \mathrm{d}$ & $\dagger$ \\
\hline Less than 25 & & & & & & \\
$\quad$ Fed & 0.128 & 198 & & 0.058 & 0.090 & 90 & 140 \\
$\quad$ Fasted & 0.089 & 137 & & 0.098 & - & 150 & - \\
Older than 25 & & & & & & \\
$\quad$ Fed & 0.075 & 230 & & 0.017 & 0.058 & 52 & 176 \\
$\quad$ Fasted & 0.052 & 156 & & 0.058 & - & 174 & - \\
\hline
\end{tabular}

$\dagger$ Protein degradation calculated as protein synthesis minus protein gain (calculated from live-weight change).

protein loss in the whole body $(P<0.05)$, due both to a decline in the rate of protein degradation and to a lesser decline in the rate of protein synthesis $(P<0.05)$ (Table 4$)$.

Fractional rates of synthesis and degradation of protein in the whole animal declined as the lambs became older, although in terms of absolute rate there was no change (Table 5). The effect of insulin on whole-body protein metabolism was proportionately similar in lambs of differing ages.

\section{Metabolism in hind-limb}

Leucine flux, interconversion of leucine and $\mathrm{KIC}$, and oxidation in hind-limb muscle are shown in Table 6. Compared with fed lambs, fasted lambs showed during saline infusions (1) a decline in the gross uptake of leucine $\left(R_{10}\right)(P<0.01)$ and the flux of leucine into the protein pool $\left(R_{41}\right)(P<0.05)$; and $(2)$ an increase in leucine efflux $\left(R_{01}\right)$ from muscle $(P<0.01)$ and muscle protein $\left(R_{14}\right)(P<0.01)$. There were no significant effects of insulin on muscle leucine or protein metabolism in fed lambs. During fasting, the effects of insulin could be classified in two ways. At the lower rate of insulin infusion, the rate of efflux of leucine from muscle $\left(R_{01}\right)$, and of transfer of leucine from protein $\left(R_{14}\right)$, were decreased $(P<0.05)$ in the insulin-treated hind-limbs compared with control (untreated) hind-limbs. The higher rate of insulin infusion resulted in equivalent reduction in the rate of leucine efflux $\left(R_{01}\right)$, rate of loss of leucine from protein $\left(R_{14}\right)$, and a reduction in leucine uptake by muscle $\left(R_{10}\right)$ and transfer into the protein pool $\left(R_{41}\right)(P<0.05)$ in both hind-limbs.

In terms of fractional rate of synthesis, degradation and gain of muscle protein (Table 7), fasted lambs had a lower rate of protein synthesis and gain $(P<0.01)$ than fed lambs, and protein degradation was increased $(P<0-05)$. Insulin had no significant effect on these variables in fed lambs. In fasted lambs, there was a decrease in the rate of protein degradation in the treated leg at the lower level of insulin infusion $(P<0.05)$. The higher level of insulin depressed $(P<0.05)$ protein degradation and protein synthesis in both hind-limbs.

In fed lambs, fractional rate of hind-limb protein synthesis and degradation declined as lambs became older. Mean values (/d) were, for $K_{s}, 0.156$ and 0.075 and for $K_{d}, 0.072$ and 0.032 in lambs less than and greater than $25 \mathrm{~d}$ of age respectively. Corresponding mean values (/d) in fasted lambs were $0.072,0.072$ for $K_{s}$ and $0.110,0 \cdot 102$ for $K_{d}$. The effect of insulin was proportionately similar in lambs of both age-groups.

Uptake of glucose across the hind-limb (as shown by arterio-venous difference), was progressively increased by insulin infusion from 0.13 to 0.22 and 0.26 (average SE 0.05 ) $\mathrm{mM}$ 
Table 6. Effect of insulin on hind-limb muscle leucine metabolism in eight fed and eight fasted lambs

(The values shown, and nomenclature used, are rates of flux ( $\mu \mathrm{mol} / \mathrm{kg}$ per $\mathrm{min}$ ) through the pathways of the scheme of leucine and $a$-ketoisocaproic acid interconversion shown in Fig. 1. The values for treated and control legs were combined where there was no difference between legs (paired $t$ test, $P>0.05)$ )

\begin{tabular}{|c|c|c|c|c|c|c|c|}
\hline \multirow[b]{2}{*}{ Rate } & \multirow[b]{2}{*}{ Treatment } & \multirow{2}{*}{$\begin{array}{l}\text { Saline infusion } \\
(9 \mathrm{~g} \text { sodium } \\
\text { chloride } / 1)\end{array}$} & \multicolumn{3}{|c|}{ First insulin infusion } & \multirow{2}{*}{$\begin{array}{l}\text { Second insulin } \\
\text { infusion }\end{array}$} & \multirow{2}{*}{$\begin{array}{c}\text { Average } \\
\text { SE }\end{array}$} \\
\hline & & & C & & $\mathrm{T}$ & & \\
\hline$R_{10}$ & $\begin{array}{c}\text { Fed } \\
\text { Fasted }\end{array}$ & $\begin{array}{l}8 \cdot 35 \\
4 \cdot 55^{a * *}\end{array}$ & & $\begin{array}{l}7 \cdot 30 \\
4 \cdot 22^{\mathrm{ab} * *}\end{array}$ & & $\begin{array}{l}6.45 \\
1.99^{\mathrm{b} * *}\end{array}$ & $\begin{array}{l}1.05 \\
1.53\end{array}$ \\
\hline$R_{01}$ & $\begin{array}{c}\text { Fed } \\
\text { Fasted }\end{array}$ & $\begin{array}{l}2.05 \\
4.93\end{array}$ & $4 \cdot 49^{a *}$ & $2 \cdot 22$ & $3 \cdot 71^{\mathrm{b}}$ & $\begin{array}{l}1 \cdot 07 \\
1 \cdot 83^{b}\end{array}$ & $\begin{array}{l}0.59 \\
0.56\end{array}$ \\
\hline$R_{02}-R_{20}$ & $\begin{array}{c}\text { Fed } \\
\text { Fasted }\end{array}$ & $\begin{array}{l}0.41 \\
0.58^{\mathrm{a}}\end{array}$ & & $\begin{array}{l}0.28 \\
0.53^{\mathrm{ab}}\end{array}$ & & $\begin{array}{c}0.25 \\
-0.03^{b}\end{array}$ & $\begin{array}{l}0 \cdot 16 \\
0 \cdot 17\end{array}$ \\
\hline$R_{12}$ & $\begin{array}{c}\text { Fed } \\
\text { Fasted }\end{array}$ & $\begin{array}{l}1.32 \\
3.90\end{array}$ & & $\begin{array}{l}1 \cdot 21 \\
0 \cdot 88\end{array}$ & & $\begin{array}{l}0.41 \\
3.41\end{array}$ & $\begin{array}{l}0.55 \\
1.89\end{array}$ \\
\hline$R_{21}$ & $\begin{array}{c}\text { Fed } \\
\text { Fasted }\end{array}$ & $\begin{array}{l}3.44 \\
5.67\end{array}$ & & $\begin{array}{l}3 \cdot 32 \\
2 \cdot 10\end{array}$ & & $\begin{array}{l}2 \cdot 94 \\
4 \cdot 39\end{array}$ & $\begin{array}{l}0.93 \\
1.97\end{array}$ \\
\hline$R_{32}$ & $\begin{array}{c}\text { Fed } \\
\text { Fasted }\end{array}$ & $\begin{array}{l}1 \cdot 75 \\
1.05\end{array}$ & & $\begin{array}{l}1 \cdot 83 \\
0.69\end{array}$ & & $\begin{array}{l}2 \cdot 21 \\
1 \cdot 04\end{array}$ & $\begin{array}{l}0 \cdot 85 \\
0 \cdot 31\end{array}$ \\
\hline$R_{14}$ & $\begin{array}{c}\text { Fed } \\
\text { Fasted }\end{array}$ & $\begin{array}{l}3 \cdot 35 \\
6 \cdot 63^{a * *}\end{array}$ & $5 \cdot 64^{a *}$ & 3.00 & $4 \cdot 36^{b}$ & $\begin{array}{l}2 \cdot 11 \\
2 \cdot 83^{\mathrm{b}}\end{array}$ & $\begin{array}{l}0.87 \\
0.31\end{array}$ \\
\hline$R_{41}$ & $\begin{array}{c}\text { Fed } \\
\text { Fasted }\end{array}$ & $\begin{array}{l}7.50 \\
4 \cdot 61^{a *}\end{array}$ & & $\begin{array}{l}6.17 \\
3.89^{\mathrm{ab} * *}\end{array}$ & & $\begin{array}{l}4.96 \\
2.08^{\mathrm{b} * *}\end{array}$ & $\begin{array}{l}1.20 \\
0.59\end{array}$ \\
\hline
\end{tabular}

C, Control leg; T, treated leg.

a,b Mean values with unlike superscript letters were significantly different $(P<0.05)$.

Mean values for fed and fasted lambs were significantly different: ${ }^{*} P<0.05,{ }^{* *} P<0.01$.

Table 7. Effect of insulin on fractional rates of protein synthesis $\left(\mathrm{K}_{\mathrm{s}}\right)$, degradation $\left(\mathrm{K}_{\mathrm{d}}\right)$ and gain $\left(\mathrm{K}_{\mathrm{g}}\right)$ in hind-limb muscle of eight fed and eight fasted lambs

(Values are means of both hind-limbs except where there was a significant $(P<0.05)$ difference between insulin-treated and control legs, for which the values are shown separately)

\begin{tabular}{|c|c|c|c|c|c|}
\hline & \multirow{2}{*}{$\begin{array}{l}\text { Saline infusion } \\
(9 \mathrm{~g} \text { sodium } \\
\text { chloride } / 1\end{array}$} & \multicolumn{2}{|c|}{ First insulin infusion } & \multirow{2}{*}{$\begin{array}{l}\text { Second insulin } \\
\text { infusion }\end{array}$} & \multirow[b]{2}{*}{ Average SE } \\
\hline & & $\mathrm{C}$ & $\mathrm{T}$ & & \\
\hline \multicolumn{6}{|l|}{$K_{\mathrm{s}}(/ \mathrm{d})$} \\
\hline Fed & $0 \cdot 115$ & \multicolumn{2}{|c|}{0.095} & $0 \cdot 076$ & $0 \cdot 019$ \\
\hline Fasted & $0.071^{\text {a* }}$ & \multicolumn{2}{|c|}{$0.060^{\mathrm{ab} *}$} & $0 \cdot 032^{\mathrm{b} *}$ & 0.009 \\
\hline \multicolumn{6}{|l|}{$K_{a t}(/ \mathrm{d})$} \\
\hline Fed & 0.052 & \multicolumn{2}{|c|}{$0 \cdot 046$} & 0.033 & $0 \cdot 013$ \\
\hline Fasted & $0 \cdot 103^{a * *}$ & $0.087^{\mathrm{a} *}$ & $0.067^{b}$ & $0 \cdot 044^{\mathrm{b}}$ & 0.011 \\
\hline \multicolumn{6}{|l|}{$K_{g}(/ \mathrm{d})$} \\
\hline Fed & 0.063 & \multirow{2}{*}{\multicolumn{2}{|c|}{$\begin{array}{c}0.049 \\
-0.015^{* *}\end{array}$}} & $0 \cdot 042$ & 0.017 \\
\hline Fasted & $0.032^{* *}$ & & & $-0.012^{* *}$ & 0.011 \\
\hline
\end{tabular}

C, control leg; T, treated leg.

Mean values with unlike superscript letters were significantly different $(P<0.05)$.

Mean values for fed and fasted lambs were significantly different: ${ }^{*} P<0 \cdot 05,{ }^{* *} P<0 \cdot 01$. 
in fed lambs, and from 0.05 to 0.08 and 0.11 (average SE 0.02) $\mathrm{mM}$ in fasted lambs, despite an accompanying decrease in circulating plasma glucose concentration from 7.56 to 5.94 and 4.63 (SE 0.55 ) $\mathrm{mm}$ in fed and from 4.51 to 3.02 and 1.70 (SE 0.21 ) $\mathrm{mm}$ in fasted lambs. The effects of adrenaline infusion on hind-limb-muscle leucine and protein metabolism were to increase lactate arterio-venous difference from -0.106 to $-1.032 \mathrm{~mm}(P<0.01)$, decrease fractional rate of protein synthesis $\left(K_{s}\right)$ from 0.100 to $0.025 / \mathrm{d}(P<0.05)$ without affecting $K_{d}(0.043 / \mathrm{d}$ during saline infusion compared with $0.053 / \mathrm{d}$ during adrenaline infusion). Together these resulted in a decreased rate of muscle protein gain $\left(K_{g}\right)$ from 0.057 to $-0.028 / \mathrm{d}(P<0.01)$ in saline and adrenaline infusions respectively. There was no difference in the rate of leucine efflux $\left(\mu \mathrm{mol} / \mathrm{kg}\right.$ per min) from hind-limb muscle $\left(R_{01}\right)$ during saline (1.91) and adrenaline infusions $(2.82)$, but adrenaline decreased $(P<0.05)$ the rate of leucine uptake $\left(R_{10}\right)$ by muscle from 7.87 to $3.96 \mu \mathrm{mol} / \mathrm{kg}$ per min. During adrenaline infusion the proportion of leucine uptake oxidized increased threefold $(P<0.05)$ from 0.22 to 0.67 .

\section{DISCUSSION}

The present results show that in fed lambs, insulin was without significant effect on protein metabolism, in muscle, or the body as a whole, despite effects on glucose metabolism. By contrast, in fasted lambs, the initial effect of insulin was to reduce the rate of protein degradation in muscle and the whole body, with subsequent reduction in protein synthesis.

It has to be recognized that the method used to estimate the rates of protein synthesis and degradation in the whole body from leucine flux gives only approximate values. No single amino acid can be regarded as generally representative of the concerted action of all, although leucine does appear to be as useful as any for this purpose (e.g. Lindsay, 1982; Obled et al. 1983). In addition the size of the flux depends on the choice of sampling site for SRA measurement, as well as the route of infusion. Venous blood will usually have a lower SRA than that of arterial blood and thus give higher estimates of flux. The venous site used, however, reflects predominantly the tissue from which it drains (see also Katz et al. 1981; Katz, 1982; Pell et al. 1983), and for both sites the SRA is usually above the intracellular SRA.

Attempts have been made to estimate the SRA of intracellular leucine by supposing that plasma KIC is a close approximation (Mathews et al. 1982; Schwenk et al. 1985). However, in the sheep and the lamb the rate of interconversion of leucine and KIC is substantially less than that in man, rat, dog and pig (Nissen \& Ostaszewski, 1985; Oddy, 1986, Pell et al. 1986), and the KIC SRA does not, therefore, serve as an adequate estimation of the intracellular leucine SRA. Furthermore, we found preferential incorporation of extracellular over intracellular leucine into protein in the hind-limb of growing lambs (Oddy, 1986). Thus, although arbitrary, the use of arterial leucine SRA as an indicator of leucine flux is as valid as any other SRA for calculating the rate of whole-body protein synthesis.

In addition, there is extensive metabolism of leucine, and of course other amino acids, in the digestive tract and liver before appearance in the peripheral circulation, particularly in fed animals. Thus the rate of leucine flux determined following intravenous administration of the radioactive label, as here, underestimates the leucine flux measured following oral administration of label (Jackson, 1986). Furthermore, there is a substantial discrepancy between leucine lost from the gut and that appearing in the portal vein of fed animals (Rerat et al. 1976; Tagari \& Bergman, 1978; Pell et al. 1986). This is particularly 
important in the calculation of rates of protein degradation (calculated as flux minus intake) for the true flux is substantially underestimated in fed compared with fasted animals.

Different limitations apply to the estimates of rates of protein synthesis and degradation in the hind-limb. As has been fully discussed by Oddy \& Lindsay (1986), the procedure is elaborate and prone to a number of errors which may be additive. Furthermore, the procedure ideally requires a steady state with respect to concentration and SRA of leucine, $\mathrm{KIC}$ and $\mathrm{CO}_{2}$ in plasma and intracellular fluid pools during the period of measurement. During insulin infusion into fasted lambs there were substantial changes in the plasma concentrations of leucine and KIC (see Fig. 2). However, the rate of change of plasma leucine concentration was slow (half-life approximately $75 \mathrm{~min}$ ) compared with the rate of turnover of leucine in plasma and intracellular pools (respective half-lives 2 and $9 \mathrm{~min}$; Wootton, 1986). Thus, although concentrations of leucine declined during insulin infusion into fasted lambs we feel that the calculated rates of protein synthesis and degradation obtained during this period are indicative of real changes in protein metabolism in the hindlimb.

In addition to these considerations there are other potential sources of error in our estimates of the rate of protein metabolism in the hind-limb. One, the possibility of systematic variation in blood flow during each experiment, was tested. Although the method used does not give absolute measurements of the rate of blood flow, it does give satisfactory relative values, and it was shown that insulin had no specific effect on blood flow in contrast to some earlier findings (Andres et al. 1962; Rabinowitz \& Zierler, 1962; Pozefsky et al. 1969). Andres et al. (1962), however, did suggest the effect was non-specific rather than due to insulin per se. Another difficulty with interpretation arises through contribution of tissues other than muscle to measurement of protein metabolism in our hind-limb preparation. Although muscle makes by far the largest contribution (about $90 \%$ ) to blood sampled in our hind-limb preparation (Oddy \& Lindsay, 1986; Teleni \& Annison, 1986), the relatively high rate of protein synthesis in the soluble proteins of bone, and perhaps skin, relative to muscle (Preedy et al. 1983), could mean that as much as $20 \%$ of protein metabolism measured in the hind-limb was by non-muscle tissues.

\section{Effect of fasting}

Fasting was clearly associated with a reduction in leucine flux and of protein synthesis in both hind-limb muscle and the whole body (see also Rennie et al. 1982; Emery et al. 1983; Garlick et al. 1983; Preedy et al. 1983; Patureau-Mirand et al. 1985). The rate of protein degradation in hind-limb muscle was also clearly increased in fasting, in contrast to the findings of Millward et al. (1976). This difference may mean very little; however, the method used by these authors (involving measurement of change in body composition) is not very precise over a short fast; moreover, their rats were relatively older than our animals, and there may be species differences. For the reasons outlined previously we were unable to conclusively show an increase in the rate of protein degradation in the whole body on fasting.

\section{Effect of insulin}

That insulin had no effect on leucine or KIC concentration, nor on the rate of synthesis or degradation of protein in fed lambs is not surprising. The concentration of insulin in arterial plasma before infusion of added insulin was high (288 (SE 88$) \mu \mathrm{U} / \mathrm{ml}$ ), food intake was unrestricted and substrate supply must be supposed optimal. Added insulin has been 
reported to increase protein deposition in fed pigs (Fuller et al. 1977), although Sumner \& Weekes (1983) were unable to obtain similar results in lambs. Nevertheless, insulin infusion significantly increased the rate of glucose uptake by hind-limb muscle. Thus carbohydrate metabolism appears more sensitive to changes in insulin concentration than does amino acid metabolism, at least in hind-limb muscle.

In fasted lambs, insulin was effective in reducing the rate of protein degradation, both in hind-limb muscle and the whole body. This is in agreement with findings in other species, for example in the muscles of diabetic rats (Albertese et al. 1979; Pain et al. 1983) and in the whole body of post-absorptive man (Fukagawa et al. 1985). The extent to which protein degradation is reduced by insulin infusion in fasting lambs is sufficient to suggest that the fall in insulin is the prime factor in accounting for the rise in the rate of protein degradation. Since elevation of the fasting insulin concentration to that normally occurring in the fed animals did result in a fall in the rate of protein degradation in the whole body, it is also plausible that there was an increase in the rate of protein degradation by the whole body during fasting, and that this occurred as a result of (among other things) the fall in the circulating insulin concentration (although for reasons already outlined, we cannot quantify the effects).

In contrast to the finding on proteolysis, insulin decreased the rate of protein synthesis seen in fasting lambs, both for the whole body and for the hind-limb muscle. This is in contrast with findings in fasted (Garlick et al. 1983; Reeds et al. 1985) and diabetic (Albertese et al. 1979; Pain et al. 1983) rats, but consistent with observations of decreased rates of muscle-protein synthesis in the fetal lamb (Horn et al. 1983) and diabetic man (Nair \& Halliday, 1985). Horn et al. (1983), however, did observe that in the presence of additional amino acids, insulin would stimulate protein synthesis in the muscle of fetal lambs. Since in the present study we made no attempt to counter the fall in leucine (and perhaps other amino acids) that occurred, presumably as a result of insulin-induced reduction of proteolysis, it is very likely that reduced substrate availability limited the effectiveness of insulin on protein synthesis.

Another possible explanation for the reduction in protein synthesis was that hypoglycaemia, induced by insulin action, resulted in increased catecholamine (mostly adrenaline) secretion (Jarret \& Potter, 1953; Setchell \& Waites, 1962), although Garlick et al. (1983) and Reeds et al. (1985) both reported increased rates of protein synthesis in the face of insulin-induced hypoglycaemia. Wool (1960) showed that adrenaline reduced the rate of incorporation of labelled amino acids into muscle protein in vitro. Our observations show that adrenaline inhibits muscle-protein synthesis in the lamb in vivo, while having no significant effect on the rate of protein degradation. In addition adrenaline infusion resulted in a significant increase in the proportion of leucine uptake oxidized by muscle (from 0.22 to 0.67 ), values comparable to those obtained during infusion of insulin in fasted lambs $(0 \cdot 21-0.59)$. In the absence of measured adrenaline concentrations during insulin infusion we cannot be sure that the effects observed on protein synthesis were due to catecholamine secretion, or to dimunition of substrate supply, although the latter seems the most plausible. Nevertheless the evidence suggests that the reduction in protein synthesis seen during insulin infusion in fasted lambs is secondary to other effects of insulin in vivo.

The lack of effect of adrenaline on the rate of muscle proteolysis may be contrasted with the findings of Miles et al. (1984) in post-absorptive man, that adrenaline infusion reduced proteolysis in the whole body. However, in their experiments there was a significant increase in plasma insulin which could have been responsible for this. We used lower rates of adrenaline infusion in our experiments, and there was no elevation in plasma insulin (results not shown), but even if insulin secretion had been stimulated our studies show that insulin would be ineffective in fed lambs. 


\section{Contribution of muscle to whole-body metabolism}

If it is assumed that in these experiments hind-limb muscle is representative of skeletal muscle in general (cf. Oddy et al. 1984) and that skeletal muscle is $27 \%$ of body-weight (Palsson \& Verges, 1952) then skeletal muscle accounted for, in fed lambs: $29 \cdot 4,29.6$ and $23.8 \%$ and in fasted lambs: $26 \cdot 1,28.7$ and $24.6 \%$ of whole-body protein synthesis during saline and the two insulin infusions respectively. Corresponding values for rates of protein degradation were : 21,49 and $35 \%$ (fed) and 34,33 and $31 \%$ in fasted lambs. Values in fed lambs could be substantially less - assuming half the visceral leucine uptake were metabolized in situ, corresponding values would be 17, 20 and $14 \%$. These results suggest that whatever assumptions are made, there is no evidence that insulin has any effect in altering the contribution of muscle to whole body protein metabolism. It would also seem that for the neonatal lamb at least, the proposal of Garlick et al. (1986) that muscle plays a major role in storage of ingested amino acids, with subsequent augmented release during a short-term fast, is unlikely to be correct.

The authors wish to thank Peter Brew for expert care of the animals used in this study. This work was funded in part by the Australian Meat and Livestock Research and Development Corporation.

\section{REFERENCES}

Agricultural Research Council (1980). The Nutrient Requirements of Ruminant Livestock. Slough: Commonwealth Agricultural Bureaux.

Albertese, E. C., Pain, V. M. \& Garlick, P. J. (1979). Proceedings of the Nutrition Society 39, 19 A.

Andres, R., Baltzan, M. A., Cadoe, G. \& Zierler, K. L. (1962). Journal of Clinical Investigation 41, 108-115.

Domanski, A., Lindsay, D. B. \& Setchell, B. P. (1974). Journal of Physiology 242, 28P 29P.

Emery, P. W., Cotellessa, L., Holness, M. \& Rennie, M. J. (1983). Proceedings of the Nutrition Society 42 , $136 \mathrm{~A}$.

Fukagawa, N. K., Minaker, K. L., Rowe, J. W., Goodman, M. N., Matthews, D. E., Bier, D. M. \& Young, V. R. (1985). Journal of Clinical Investigation 76, 2306-2311.

Fuller, M. F., Weekes, T. E. C., Cadenhead, A. \& Bruce, J. B. (1977). British Journal of Nutrition 38, $489-496$.

Garlick, P. J., Fern, M. \& Preedy, V. R. (1983). Biochemical Journal 210, 669-676.

Garlick, P. J., McNurlan, M. A., McHardy, K. G., Reeds, P. J., Preedy, V. R. \& Clugston, G. A. (1986). In Proceedings of the XIII International Nutrition Congress, pp. 374-377 [T. G. Taylor and N. K. Jenkins, editors]. London: John Libbey.

Gutmann, I. \& Wahlefeld, A. W. (1974). In Methods of Enzymatic Analysis, vol. 3, pp. 1464-1468 [H. U. Bergmeyer, editor]. New York: Academic Press.

Horn, J., Stern, M. D. R., Young, M. \& Noakes, D. E. (1983). Research in Veterinary Science 35, 35-41.

Jackson, A. A. (1986). In Proceedings of the XIII International Congress of Nutrition, pp. 403-409 [T. G. Taylor and N. K. Jenkins, editors]. London: John Libbey.

Jarrett, I. G. \& Potter, B. J. (1953). Australian Journal of Experimental Biology and Medicine 31, 311-318.

Katz, J. (1982). Federation Proceedings 41, 123-128.

Katz, J., Okajima, F., Chenoweth, M. \& Dunn, A. (1981). Biochemical Journal 194, 513-524.

Lindsay, D. B. (1982). Federation Proceedings 41, 2550-2554.

Mathews, D. E., Schwarz, H. P., Yang, R. D., Motil, K. J., Young, V. R. \& Bier, D. M. (1982), Metabolism 31, $1105-1112$.

Miles, J. M., Nissen, S. L., Gerich, J. E. \& Haymond, M. W. (1984). American Journal of Physiology 247, E166-E172.

Millward, D. J., Garlick, P. J., Nnanyelugo, D. O. \& Waterlow, J. C. (1976). Biochemical Journal 156, 185-188.

Nair, K. S. \& Halliday, D. (1985). In Substrate and Energy Metabolism in Man, pp. 195-202 [J. S. Garrow and D. Halliday, editors]. London: John Libbey.

Nissen, S. \& Ostaszewski, P. (1985). British Journal of Nutrition 54, 705-712.

Obled, C., Arnal, M. \& Fauconneau, G. (1983). In 4th International Symposium of Protein Metabolism and Nutrition, pp. 23-27 [M. Arnal, R. Pion and D. Bonin, editors]. Paris: INRA.

Oddy, V. H. (1986). Muscle protein metabolism: measurement and manipulation in lambs. PhD thesis, University of Cambridge. 
Oddy, V. H., Brown, B. W. \& Jones, A. W. (1981). Australian Journal of Biological Sciences 34, 419-425.

Oddy, V. H., Gooden, J. M. \& Annison, E. F. (1984). Australian Journal of Biological Sciences 37, 375-388.

Oddy, V. H. \& Lindsay, D. B. (1986). Biochemical Journal 233, 417-425.

Pain, V. M., Albertese, E. C. \& Garlick, P. J. (1983). American Journal of Physiology 245, E604-E610.

Palsson, H. \& Verges, J. B. (1952). Journal of Agricultural Science, Cambridge 42, 1-92.

Pappenheimer, J. R. \& Setchell, B. P. (1972). Journal of Physiology 226, 48P-50P.

Patureau-Mirand, P., Bernard, O., Prugnaud, J. \& Arnal, M. (1985). Reproduction Nutrition Developpement 25, 1061-1073.

Pell, J. M., Calderone, E. M. \& Bergman, E. N. (1983). Biochemical Journal 214, 1015-1018.

Pell, J. M., Calderone, E. M. \& Bergman, E. N. (1986). Metabolism 35, 1005-1016.

Pozefsky, T., Felig, P., Tobin, J. D., Soeldner, J. S. \& Cahill, G. F. (1969), Journal of Clinical Investigation 48, 2273-2282.

Preedy, V. R., McNurlan, M. A. \& Garlick, P. J. (1983). British Journal of Nutrition 49, $517-523$.

Prior, R. L. \& Smith, S. B. (1982). Federation Proceedings 40, 2545-2549.

Rabinowitz, D. \& Zierler, K. L. (1962). Journal of Clinical Investigation 41, 2191-2197.

Reeds, P. J., Hay, S. M., Glennie, R. T., Mackie, W. S. \& Garlick, P. J. (1985). Biochemical Journal 227, 255-261.

Rennie, M. J., Edwards, R. H. T., Halliday, D., Matthews, D. E., Wolman, S. L. \& Millward, D. J. (1982). Clinical Science 63, 519-523.

Rerat, A., Corring, T. \& Laplace, J. P (1976). In Protein Metabolism and Nutrition, European Association of Animal Production Publication no. 16, pp. 97-138 [D. J. A. Cole, K. N. Boorman, P. J. Buttery, D. Lewis, R. J. Neele and H. Swan, editors]. London: Butterworths.

Schwenk, W. F., Beaufrere, B. \& Haymond, M. W. (1985). American Journal of Physiology 249, E646-E650.

Setchell, B. P. \& Waites, G. M. (1962). Journal of Physiology 164, 200-209.

Sumner, R. \& Weekes, T. E. C. (1983). Proceedings of the Nutrition Society 42, 39A.

Tagari, H. \& Bergman, E. N. (1978). Journal of Nutrition 108, 790-803.

Teleni, E. \& Annison, E. F. (1986). Australian Journal of Biological Sciences 39, 271-281.

Walker, D. M. (1967). British Journal of Nutrition 21, 289-308.

Waterlow, J. C., Garlick, P. J. \& Millward, D. J. (1978). Protein Turnover in Mammalian Tissues and in the Whole Body. Amsterdam: North-Holland.

Werner, W., Rey, H.-G. \& Wielinger, H. (1970) Zeitschriftfur Analytische Chemie 252, 224-228.

Whitelaw, F. G., Brockway, J. M. \& Reid, R. S. (1972). Quarterly Journal of Experimental Physiology 57, 37-55.

Williams, A. P. (1978) Journal of Agricultural Science, Cambridge 90, 617-624.

Wool, I. R. (1960). American Journal of Physiology 198, 54-56.

Wootton, R. (1985). In Substrate and Energy Metabolism in Man, pp. 16-26 [J. S. Garrow and D. Halliday, editors]. London: John Libbey. 